\title{
PENGARUH KUALITAS SDM, MOTIVASI KERJA, PEMANFAATAN SISTEM INFORMASI, PENGENDALIAN INTERN DAN KOMITMEN ORGANISASI PADA KUALITAS LAPORAN KEUANGAN PEMERINTAH DAERAH (Studi Empiris Pada SKPD Kabupaten Klungkung)
}

\author{
Komang Krishna Yogantara ${ }^{1}$ \\ Gde Herry Sugiarto Asana ${ }^{2}$ \\ Universitas Triatma Mulya ${ }^{1}$ \\ email: krishna.yogantara@triatmamulya.ac.id
}

\begin{abstract}
The problem raised in this research is whether the quality of human resources $\left(X_{1}\right)$ has an effect on the quality of the financial statements $(Y)$ of the local government of Klungkung Regency. Work motivation $\left(X_{2}\right)$ affects the quality of financial reports $(Y)$ of the local government of Klungkung Regency. The use of information systems $\left(X_{3}\right)$ affects the quality of financial reports $(Y)$ of the local government of Klungkung Regency. Internal control $\left(X_{4}\right)$ affects the quality of financial reports $(Y)$ of the local government of Klungkung Regency. Organizational commitment $\left(X_{5}\right)$ affects the quality of financial reports $(Y)$ of the local government of Klungkung Regency. The population in this research amounted to 80 people. The data analysis technique used is validity test, reliability test, classical assumption test, multiple linear analysis, $F$ test, $t$ test and analysis of determination. The results of the analysis show the regression model $=$ $9.549+0.157 X_{1}+0.249 X_{2}+0.306 X_{3}+0.234 X_{4}+0.255 X_{5}+e$. The conclusions obtained are the quality of human resources, work motivation, utilization of information systems, internal control and organizational commitment have a positive and significant effect on the quality of financial reports.
\end{abstract}

Keywords: Internal Control, Organizational Commitment, Quality of Financial Reports, Quality of Human Resources, Utilization of Information Systems, and Work Motivation.

\section{PENDAHULUAN}

Tata kelola pemerintahan yang baik berkaitan dengan upaya reformasi birokrasi, penegakan supremasi hukum, transparansi, kepedulian terhadap pemangku kepentingan, akuntabilitas, visi strategis serta menuntut perubahan pola berpikir. Akuntabilitas adalah sebagai bentuk kewajiban mempertanggungjawabkan keberhasilan atau kegagalan pelaksanaan misi organisasi dalam mencapai tujuan dan sasaran yang telah ditetapkan sebelumnya melalui suatu media pertanggungjawaban yang dilaksanakan secara periodik. Salah satu indikator kinerja pemerintah daerah di bidang pengelolaan keuangan ditunjukkan dari keluaran berupa kualitas laporan keuangan yang diwujudkan oleh opini laporan keuangan pemerintah daerah 
berdasarkan audit oleh Badan Periksa Keuangan (BPK). Kriteria atau tolak ukur yang digunakan oleh BPK dalam melakukan pemeriksaan opini tersebut didasarkan pada peraturan perundang-undangan. Guna mendapatkan opini laporan terbaik, para pihak terkait dengan pengelolaan keuangan pemerintah daerah dan penyusunan laporan keuangan daerah harus memahami dan menerapkan ketentuan tersebut dengan baik.

Penelitian ini dilaksanakan di Kabupaten Klungkung sebagai salah satu Kabupaten yang pada hasil pemeriksaan BPK tahun 2015 untuk LKPD tahun 2015 memperoleh opini WDP. Opini WDP ini bukan merupakan suatu hasil yang maksimal serta mengindikasikan bahwa masih banyak kelemahan dalam pencatatan dan pelaporan keuangan daerah yang perlu diperbaiki (Indriasih, 2014). Permasalahan yang menghambat Kabupaten Klungkung untuk mencapai opini WTP berdasarkan laporan hasil pemeriksaan (LHP) BPK RI tahun 2015 atas LKPD Kabupaten Klungkung tahun 2014 dilihat dari temuan Sistem Pengendalian Intern (SPI) dan temuan kepatuhan. Pokok-pokok kelemahan dalam sistem pengendalian intern atas laporan keuangan Pemerintah Kabupaten Klungkung yang ditemukan BPK, sebagai berikut.

1) Pengeloaan pajak hotel dan restoran pada Pemerintah

Kabupaten Klungkung tidak sesuai dengan ketentuan.

2) Penatausahaan aset tetap Pemerintah Kabupaten Klungkung tidak tertib.

3) Penatausahaan Pajak Bumi dan Bangunan (PBB) tidak tertib.

Selain itu terdapat pula beberapa kelemahan yang dijelaskan dalam laporan BPK, berupa temuan kepatuhan sebagai berikut :

1) Penetapan surat ketetapan pajak air dan tanah oleh bidang pajak Kabupaten Klungkung Tahun 2014 kurang memadai.

2) Belanja barang dan jasa pada Dinas Pendidikan Pemuda dan Olahraga tidak sesuai ketentuan.

3) Laporan pertanggungjawaban pengguna dana atas belanja bantuan sosial dan hibah belum disampaikan kepada Bupati Klungkung.

4) Dana BOS dari Pemerintah Pusat tidak disajikan dalam Laporan Keuangan Daerah Kabupaten Klungkung.

Laporan keuangan pemerintah daerah (LKPD) yang disajikan pemerintah daerah harus mampu memberikan informasi keuangan yang berkualitas. Laporan keuangan yang berkualitas tak luput dari campur tangan sumber daya manusia yang berkualitas. Peran sumber daya manusia sangat penting dalam penyusunan laporan keuangan, dimana sumber daya manusia yang bekerja pada seluruh SKPD harus memiliki kualitas yang sangat bagus sehingga dapat menghasilkan laporan keuangan berkualitas.

Sumber daya manusia yang memiliki kompetensi akan dapat menyelesaikan pekerjaannya secara efisien dan efektif. Adanya kompetensi sumber daya manusia maka akan mendukung ketepatan waktu pembuatan laporan keuangan (Punjanira, 2017). Penelitian yang dilakukan Firdaus (2015) dan Darmayani, (2014) menyatakan bahwa kualitas sumber daya manusia berpengaruh positif pada 
kualitas laporan keuangan pemerintah daerah artinya semakin rendahnya tingkat kualitas sumber daya manusia yang dimiliki oleh Pejabat Pengelola Keuangan (PPK) dan Pembantu PKK tentang akuntansi pemerintah daerah, maka akan berdampak rendahnya kualitas laporan keuangan yang disajikan. Namun penelitian ini tidak sejalan dengan penelitian Desi Indriasari, (2008) yang menyimpulkan pengaruh sumber daya manusia tidak berpengaruh signifikan.

Selain kompetensi, kinerja pegawai pemerintah juga sangat dipengaruhi oleh motivasi kerja yang bukan hanya diukur secara finansial tetapi ada yang bersifat internal. Salah satunya faktor internal adalah motivasi yang secara langsung maupun tidak langsung dapat berpengaruh terhadap kinerja pegawai. Semakin tinggi motivasi yang dimiliki individu, maka semakin besar kemungkinannya bahwa ia akan tetap menjadi anggota organisasi maupun perusahaan. Menurut Lodhrakentjana (2019) motivasi kerja berpengaruh positif terhadap kualitas laporan keuangan yang dihasilkan. Sedangkan menurut Kartopawiro (2018) menyatakan bahwa motivasi kerja berpengaruh negatif terhadap kualitas laporan keuangan.

Pemerintah daerah juga perlu memperhatikan faktor lain diluar kompetensi SDM dan movitasi pegawai agar dapat meningkatkan kinerja para pegawainya. Menurut Sari et al, (2014) pemanfaatan sistem informasi juga sangat penting dalam menciptakan sebuah laporan keuangan yang berkualitas. Pemanfaatan sistem informasi akuntansi keuangan daerah merupakan penerapan sistem dimulai dari pengelompokkan, penggolongan, pencatatan dan pemrosesan aktivitas keuangan pemerintah daerah ke dalam sebuah laporan keuangan sebagai suatu informasi yang nantinya dapat digunakan oleh pihak tertentu dalam pengambilan keputusan oleh masing-masing SKPD dalam proses penyusunan laporan keuangan pemerintah daerah. Ogah (2013) menyatakan berkembangnya teknologi yang sangat pesat untuk saat ini, sangatlah berpengaruh pada perkembangan sistem informasi akuntansi. Sehingga perlu adanya peningkatan dalam pengaplikasian sistem informasi keuangan daerah serta pengawasan dalam pengelolaan keuangan daerah. Pujiswara et al, (2014) dan Arlia, (2016) dalam penelitiannya menyatakan bahwa pemanfaatan sistem informasi berpengaruh positif pada kualitas laporan keuangan pemerintah daerah dikarenakan pemerintah daerah wajib memperhatikan nilai informasi yang disajikan dalam laporan keuangan untuk keperluan perencanaan, pengendalian, dan pengambilan keputusan.

Sistem pengendalian intern juga sangat berperan penting dalam penyusunan laporan keuangan pemerintah daerah jika tidak ada sistem pengendalian intern pada suatu SKPD maka tidak akan ada yang mampu untuk mengarahkan dan mengawasi dalam penyusunan laporan keuangan pemerintah daerah. Sistem pengendalian intern merupakan salah satu tolak ukur yang harus di gencarkan pemerintah daerah dalam penyusunan laporan keuangan. Karena sistem pengendalian intern mampu membentuk struktur organisasi, metode dan ukuran-ukuran yang dikoordinasikan untuk menjaga kekayaan organisasi, mengecek 
ketelitian dan keandalan data akuntansi, mendorong efesiensi dan dipatuhinya kebijakan pemerintah daerah (Udiyanti et al, 2014). Penelitian sebelumnya tentang sistem pengendalian intern dilakukan oleh Indriasari, (2008) yang membuktikan secara empiris bahwa pengendalian internal pemerintah daerah berpengaruh terhadap nilai laporan keuangan pemerintah daerah yang dinyatakan dengan ketepat waktuan dan keterandalan. Hal ini didukung oleh penelitian yang dilakukan oleh Choirunisah, (2008), Irwan, (2011), Yudianta, (2012), Mahaputra, (2014), dan Nurillah, (2014) yang menyatakan bahawa sistem pengendalian intern berpengaruh positif dan signifikan terhadap kualitas laporan keuangan pemerintah daerah. Hasil penelitian berbeda ditunjukkan oleh Setiyawati, (2013) dan Yensi, (2014) bahwa sistem pengendalian intern tidak berpengaruh terhadap kualitas laporan keuangan pemerintah daerah, sedangkan Karmila, (2014) menyatakan bahwa sistem pengendalian intern tidak berpengaruh signifikan terhadap keterandalan pelaporan keuangan SKPD.

Dalam penyusunan laporan keuangan pemerintah daerah perlu adanya komitmen disetiap organisasi yang diberikan tanggungjawab dalam penyusunan laporan keuangan agar dapat mencapai suatu tujuan organisasi tersebut yaitu menghasilkan laporan keuangan pemerintah daerah yang relevan, andal, dapat dipahami dan dapat dibandingkan. Pada penelitian Noprial, (2015) hasil penelitian ini menunjukkan bahwa komitmen organisasi berpengaruh signifikan terhadap kualitas laporan keuangan. Hal ini mengindikasikan bahwa jika komitmen organisasi dalam setiap SKPD baik, maka akan mempengaruhi hasil laporan keuangan SKPD tersebut. Jika komitmen organisasi SKPD baik, maka akan menghasilkan laporan keuangan yang baik pula. Berdasarkan uraian diatas dan juga dari hasil penelitian-penelitian terdahulu, maka peneliti tertarik untuk melakukan penelitian lebih lanjut yang berjudul: "Pengaruh Kualitas Sumber Daya Manusia, Motivasi Kerja, Pemanfaatan Sistem Informasi, Pengendalian Intern dan Komitmen Organisasi pada Kualitas Laporan Keuangan Pemerintah Daerah ( Studi Empiris pada SKPD Kabupaten Klungkung)".

Adapun rumusan masalah dalam penelitian ini adalah apakah kualitas sumber daya manusia, motivasi kerja, pemanfaatan sistem informasi, pengendalian intern, dan komitmen organisasi berpengaruh terhadap kualitas laporan keuangan pemerintah daerah Kabupaten Klungkung. Dengan tujuan penelitian untuk mengetahui pengaruh kualitas sumber daya manusia, motivasi kerja, pemanfaatan sistem informasi, pengendalian intern, dan komitmen organisasi terhadap kualitas laporan keuangan pemerintah daerah Kabupaten Klungkung. Dengan adanya penelitian ini diharapkan dapat memberikan bukti empiris yang menambah wawasan di bidang akuntansi yang berkaitan dengan bidang akuntansi sektor publik khususnya tentang pengaruh kualitas sumber daya manusia, motivasi kerja, pemanfaatan sistem informasi, pengendalian intern dan komitmen organisasi terhadap kualitas laporan 
keuangan pemerintah daerah. Serta dapat dapat memberikan referensi tambahan dalam memperkaya kepustakaan bagi peneliti selanjutnya, khususnya tentang pengaruh kualitas sumber daya manusia, motivasi kerja, pemanfaatan sistem informasi, pengendalian intern dan komitmen organisasi terhadap kualitas laporan keuangan pemerintah daerah. Penelitian ini juga diharapkan dapat memberikan informasi terkait dengan kinerja pemerintahan daerah agar dapat meningkatkan kualitas laporan keuangan daerah.

\section{TINJAUAN PUSTAKA Teori Kepatuhan}

Teori kepatuhan telah diteliti pada ilmu-ilmu sosial khususnya di bidang psikologi dan sosiologi yang lebih menekankan pada pentingnya proses sosialisasi dalam mempengaruhi perilaku kepatuhan seorang individu. Terdapat dua perspektif dasar dalam literatur sosiologi mengenai kepatuhan pada hukum, yang disebut instrumental dan normatif (Faristiana, 2011). Perspektif instrumental mengasumsikan individu secara utuh didorong oleh kepentingan pribadi dan tanggapan terhadap perubahan-perubahan dalam tangible, insentif, dan penalti yang berhubungan dengan perilaku. Perspektif normatif berhubungan dengan apa yang orang anggap sebagai moral dan berlawanan dengan kepentingan pribadi mereka. Seorang individu cenderung mematuhi hukum yang mereka anggap sesuai dan konsisten dengan norma-norma internal mereka.

\section{Kualitas Sumber Daya Manusia}

Menurut Syafarudin, (2008), Kualitas sumber daya manusia adalah sebagai kunci keuanggulan kompetitif
bagi organisasi. Membentuk
kompetensi- kompetensi dan
komitmen pegawai baik secara individu atau kelompok guna memenuhi kebutuhan organisasi dan mengintegrasikan kompetensi- kompetensi tersebut dalam sistem manajemen yang dijalankan organisasi.

\section{Motivasi Kerja}
Menurut Kadarisman (2012: 278) motivasi kerja adalah penggerak atau pendorong dalam diri seseorang untuk mau berperilaku dan bekerja dengan giat dan baik sesuai dengan tugas dan keajaiban yang telah diberikan. Menurut Anwar Prabu Mangkunegara (2005: 61) motivasi merupakan kondisi atau energi yang menggerakkan diri karyawan yang terarah atau tertuju untuk mencapai tujuan organisasi.

\section{Sistem Informasi}

Sistem informasi (information system) adalah serangkaian prosedur formal di mana data dikumpulkan, diproses menjadi informasi dan didistribusikan ke para pengguna. Sistem informasi menerima input yang disebut transaksi, yang akan dikonversikan melalui berbagai proses menjadi informasi output, yang akan diberikan ke pengguna.

\section{Pengendalian Intern}

IAPI, (2011) mendefinisikan pengendalian intern sebagai suatu proses yang dijalankan oleh dewan komisaris, manajemen dan personel lain entitas yang didesain untuk memberikan keyakinan memadai tentang pencapaian tiga golongan tujuan berikut ini: (a) keandalan pelaporan keuangan, (b) efektivitas dan efisiensi operasi, dan (c) kepatuhan terhadap hukum dan peraturan yang berlaku (Agoes, 2012). 


\section{Komitmen Organisasi}

Komitmen

organisasi

merupakan suatu keadaan dimana seorang individu memihak organisasi serta tujuan-tujuan dan keinginan untuk memperhatikan keanggotaannya dalam organisasi (Dewi, 2014). Komitmen organisasi juga dapat menunjukkan bahwa dalam diri individu tersebut terdapat dorongan untuk berbuat sesuatu agar dapat membantu keberhasilan organisasi sesuai dengan tujuan organisasi dan lebih mengutamakan kepentingan organisasi tempatnya berada.

\section{Kualitas Laporan Keuangan Pemerintah Daerah}

Kualitas laporan keuangan pemerintah terangkum sebagai suatu ciri khas informsi yang menjadi representasi proses transaksai keuangan yang terjadi selama satu periode, sebagai bentuk pertanggungjawaban pemerintah kepada rakyat atas pengelolaan dana publik. Komponen-komponen yang terdapat dalam suatu laporan keuangan pokok menurut PP Nomor 71 Tahun 2010 tentang Standar Akuntansi Pemerintahan pada paragrap 28.

\section{Penelitian Terdahulu}

Beberapa penelitian sebelumnya menyatakan pengaruh kualitas sumber daya manusia memiliki pengaruh positif terhadap kualitas laporan keuangan. Seperti penelitian yang dilakukan oleh Adhi (2013) dengan judul penelitian Pengaruh Penerapan Standar Akuntansi Pemerintahan dan Kualitas Sumber daya manusia Pemerintah Daerah Terhadap Kualitas Laporan Keuangan (Studi kasus pada pemerintah kota tual) pada Jurnal Akuntansi, Vol. 5 No. 3, Hal, 1-19 menyatakan bahwa kualitas sumber daya manusia berpengaruh secara positif terhadap kualitas laporan keuangan.

Kerangka Konseptual dan

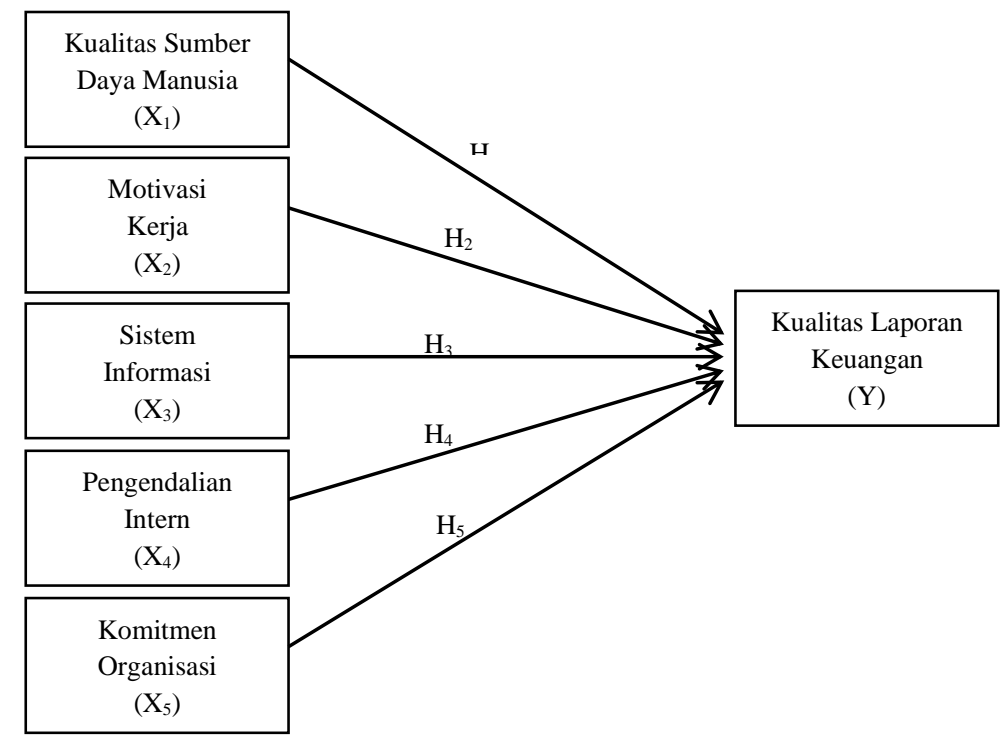

GAMBAR 2.1

KERANGKA KONSEPTUAL

Sumber : Data diolah, 2021 


\section{Hipotesis Penelitian}

1) Pengaruh kualitas sumber daya manusia terhadap kualitas laporan keuangan pemerintah daerah

Keterkaitan antara

kualitas sumber daya manusia dengan kualitas laporan keuangan pemerintah daerah didukung oleh teori agency theory, teori ini digunakan untuk menjelaskan bahwa adanya hubungan antara rakyat sebagai prinsipal dan pemerintah sebagai agen, sehingga diperlukannya kualitas sumber daya manusia yang baik di seluruh instansi pemerintahan untuk memenuhi kebutuhan rakyat (prinsipal) dan memberikan pertanggungjawaban menyajikan, melaporkan dan mengungkapkan segala aktivitas kegiatan yang menjadi tanggung jawabnya kepada rakyat seperti menghasilkan laporan keuangan pemerintah daerah yang berkualitas. Pendapat ini didukung dengan beberapa penelitian tentang kualitas sumber daya manusia yang dilakukan oleh Aryani, (2013), Adhi dan Suharjo, (2013), Yudianta dan Erawati, (2013), Afiah (2014) yang menemukan bahwa kualitas sumber daya manusia itu berpengaruh positif terhadap kualitas laporan keuangan.

$\mathrm{H}_{1}$ : Kualitas sumber daya manusia berpengaruh positif pada kualitas laporan keuangan di SKPD Kabupaten Klungkung

2) Pengaruh motivasi kerja terhadap kualitas laporan keuangan pemerintah daerah

Menurut Winardi (2007), motivasi adalah hasil sejumlah proses yang bersifat internal atau eksternal bagi seseorang individu, yang menyebabkan timbulnya sikap antusiasme dan persistensi dalam hal melaksanakan kegiatankegiatan tertentu. Faktor yang diperhitungkan untuk meningkatkan semangat dan gairah kerja pegawai dalam organisasi apapun adalah adanya motivasi dan kemampuan kerja yang dimiliki pegawainya. Pendapat ini didukung dengan beberapa penelitian terdahulu yakni Lodhrakentjana (2019) dan Sumarti (2007) yang menyatakan bahwa motivasi berpengaruh positif terhadap kualitas laporan keuangan.

$\mathrm{H}_{2}$ : Motivasi kerja berpengaruh positif pada kualitas laporan keuangan di SKPD Kabupaten Klungkung

3) Pengaruh sistem informasi terhadap kualitas laporan keuangan pemerintah daerah

Sistem informasi akuntansi yang menjadi suatu bagian yang sangat penting dalam sistem informasi yang dapat menerima data mentah keuangan dan memprosesnya menjadi suatu informasi untuk kepentingan baik untuk kepentingan luar dan dalam suatu organisasi (Iman, 2012). Agar manfaat dan tujuan penyajian laporan keuangan pemerintah dapat dipenuhi maka informasi yang disajikan merupakan informasi yang bermanfaat bagi pihak yang berkepentingan dengan informasi tersebut. Hasil penelitian Pujiswara et. al, (2014), Sari et. al, (2014) dan Yuliani et.al, (2010) menyatakan bahwa pemanfaatan sistem informasi 
Journal of Applied Management and Accounting Science. (JAMAS)

(Komang Krishna Yogantara, Gde Herry Sugiarto Asana 85 - 103)

Vol 3, No 1, Desember 2021

\begin{tabular}{|c|c|c|}
\hline & berpengaruh & Komitmen \\
\hline & kualitas laporan keuangan & adalah dorongan dari dalam \\
\hline & pemerintah daerah. & individu dalam organisasi untuk \\
\hline & $\mathrm{H}_{3}$ : Pemanfaatan & berbuat sesuatu agar dapat \\
\hline & berpengaruh & keberhasilan \\
\hline & positif pada kualitas laporan & organisasi tersebut sesuai dengan \\
\hline & keuangan di SKPD & tujuan organisasi dan lebih \\
\hline & Kabupaten Klungkung & mengutamakan \\
\hline 4) & Pengaruh pengendalian intern & organisasi dibandingkan dengan \\
\hline & kualitas laporan & kepentingan individu itu sendiri. \\
\hline & keuangan pemerintah daerah & Menurut Porter, Mowday dan \\
\hline & $\begin{array}{cc}\text { Hubungan antara } & \text { sistem } \\
\text { pengendalian intern dengan }\end{array}$ & $\begin{array}{l}\text { Steers, (1974) karyawan yang } \\
\text { memiliki komitmen organisasi }\end{array}$ \\
\hline & kualitas laporan keuangan & tinggi akan lebih termotivasi \\
\hline & pemerintah daerah didukung oleh & untuk hadir dalam organisasi dan \\
\hline & teori kepatuhan dimana & berusaha untuk mencapai tujuan \\
\hline & pengendalian intern & organisasi. Hasil penelitian yang \\
\hline & untuk memberikan keyakinan & dilakukan oleh Noprial (2015), \\
\hline & memadai bahwa LKPD harus & Julita, (2010) dan Mohmmaed and \\
\hline & disajikan secara wajar sesuai & Eleswed, (2013) menyatakan \\
\hline & dengan prinsip akuntansi di & komitmen pegawai \\
\hline & Indonesia, kepatuhan terhadap & organisasi \\
\hline & hukum dan peraturan yang & meningkatkan kualitas \\
\hline & berlaku dan peningkatan kegiatan & keuangan. \\
\hline & operasi secara efektif dan efisien. & $\mathrm{H}_{5}:$ Komitmen \\
\hline & Penelitian mengenai pentingnya & berpengaruh positif pada \\
\hline & sistem pengendalian intern dalam & kualitas laporan keuangan di \\
\hline & meningkatkan kualitas laporan & SKPD Kabupaten \\
\hline & keuangan telah dilakukan oleh & Klungkung \\
\hline
\end{tabular}
banyak peneliti yaitu Irwan, (2011), Sari, (2012), Yudianta, (2012), Mahaputra, (2014), dan Nurillah, (2014) membuktikan secara empiris bahwa sistem pengendalian internal memiliki pengaruh signifikan terhadap kualitas laporan keuangan pemerintah daerah.

$\mathrm{H}_{4}$ : Pengendalian intern berpengaruh positif pada kualitas laporan keuangan pemerintah daerah di SKPD Kabupaten Klungkung

5) Pengaruh komitmen organisasi terhadap kualitas laporan keuangan pemerintah daerah

\section{METODE PENELITIAN}

Penelitian ini dilaksanakan di Kabupaten Klungkung sebagai salah satu Kabupaten yang pada hasil pemeriksaan BPK tahun 2015 untuk LKPD tahun 2015 memperoleh opini WDP. Opini WDP ini bukan merupakan suatu hasil yang maksimal serta mengindikasikan bahwa masih banyak kelemahan dalam pencatatan dan pelaporan keuangan daerah yang perlu diperbaiki (Indriasih, 2014). Variabel yang digunakan dalam penelitian ini adalah variabel bebas dan variabel terikat. Variabel bebas atau independen yang dianalisis pada penelitian ini adalah kualitas sumber 
daya manusia, motivasi kerja, pemanfaatan sistem informasi, pengendalian intern dan komitmen organisasi. Variabel bebas atau independen yang dianalisis pada penelitian ini adalah kualitas sumber daya manusia, motivasi kerja, pemanfaatan sistem informasi, pengendalian intern dan komitmen organisasi.

Metode pengambilan sampel yang digunakan dalam penelitian ini adalah purposive sampling yaitu teknik penentuan sampel dengan pertimbangan tertentu. Jumlah populasi dalam penelitian ini sebanyak 1002 pegawai yang bekerja di 20 SKPD di Pemerintahan Kabupaten Klungkung. Sampel dalam penelitian ini adalah sebanyak 80 responden.Teknik pengumpulan data yang digunakan adalah metode survei berupa kuesioner, yaitu dengan cara memberikan serangkaian pertanyaan atau pernyataan tertulis kepada responden untuk dijawab. Kuesioner yang disebarkan berupa daftar pernyataan tertulis kepada respoden mengenai kualitas laporan keuangan, kualitas sumber daya manusia, motivasi kerja, pemanfaatan sistem informasi, pengendalian intern dan komitmen organisasi. Masing-masing variabel tersebut disiapkan dengan jumlah pertanyaan yang berbeda satu dengan yang lainnya. Jenis data yang digunakan dalam penelitian ini adalah data kuantitatif dan data kualitatif. Data kuantitatif yang digunakan dalam penelitian ini adalah data-data hasil kuesioner. Data kualitatif dalam penelitian ini adalah gambaran umum dari Satuan Kerja Perangkat Daerah (SKPD) Kabupaten Klungkung dan daftar pernyataan dalam kuesioner. Sumber data yang digunakan dalam penelitian ini adalah data primer dan data sekunder. Data primer yang dikumpulkan dalam penelitian ini diperoleh dari hasil kuesioner yang disebarkan kepada responden. Data sekunder dalam penelitian ini adalah studi-studi empiris yang telah dilakukan oleh peneliti sebelumnya yang berkaitan dengan variabel Kualitas Sumber Daya Manusia, Motivasi kerja Pemanfaatan Sistem Informasi, Pengendalian Intern, Komitmen organisasi dan Kualitas Laporan Keuangan Pemerintah Daerah serta data yang berupa jumlah pegawai di SKPD Kabupaten Klungkung dan daftar nama SKPD yang ada di Kanupaten Klungkung. Teknik analisis data yang digunakan pada penelitian ini yakni dengan metode regresi linier berganda dengan pengujian hipotesis menggunakan uji statistik t.

\section{HASIL DAN PEMBAHASAN}

\section{Instrumen penelitian}

a. Hasil Uji Validitas

Berdasarkan hasil uji menunjukkan semua variabel memiliki nilai koefisien korelasi berada di atas 0,3 sehingga layak dijadikan instrumen penelitian.

b. Hasil Uji Reliabilitas

Berdasarkan hasil uji
menunjukkan semua variabel
memiliki nilai koefisien Alpha
Cronbach berada di atas 0,6
sehingga semua instrumen
tersebut adalah reliabel,
sehingga layak dijadikan
instrumen penelitian.

2. Hasil Uji Asumsi Klasik

a. Hasil Uji Normalitas

Berdasarkan hasil uji menunjukkan bahwa nilai Asymp.Sig (2-tailed) sebesar 0,978. Karena Asymp. Sig ( $p$ - 
Journal of Applied Management and Accounting Science. (JAMAS)

(Komang Krishna Yogantara, Gde Herry Sugiarto Asana 85 - 103)

Vol 3, No 1, Desember 2021

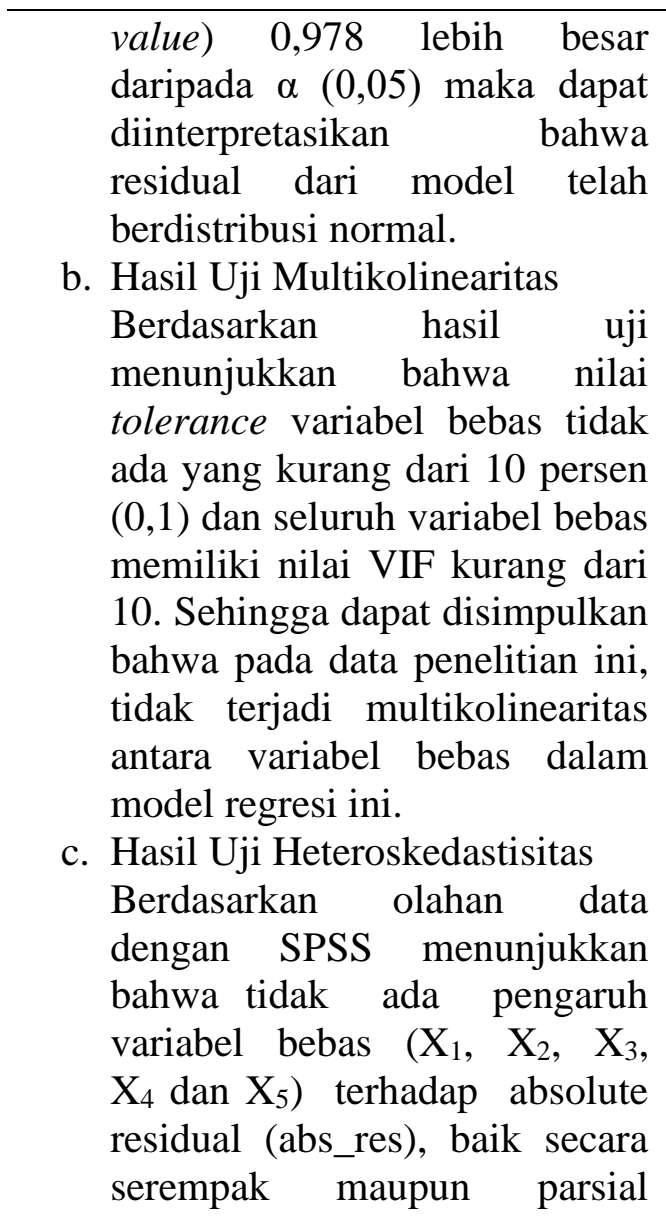

karena nilai Sig. lebih besar dari 0,05. Dengan demikian model yang dibuat tidak mengandung gejala heteroskedastisitas, sehingga layak digunakan untuk memprediksi.

\section{Hasil Analisis Regresi Linier Berganda}

Dalam model analisis pada penelitian ini, yang digunakan sebagai variabel bebas adalah adalah Kualitas Sumber Daya Manusia $\left(\mathrm{X}_{1}\right)$, Motivasi Kerja $\left(\mathrm{X}_{2}\right)$ Pemanfaatan Sistem Informasi $\left(\mathrm{X}_{3}\right)$, Pengendalian Intern $\left(\mathrm{X}_{4}\right)$, dan Komitmen Organisasi $\left(\mathrm{X}_{5}\right)$. Sedangkan yang digunakan sebagai variabel terikat pada penelitian ini adalah Kualitas Laporan Keuangan Pemerintah Daerah (Y). Analisis ini menggunakan bantuan SPSS Statistics 21.0 dalam pengolahan.

Tabel 1

Hasil Uji Determinasi

Model Summary

\begin{tabular}{|c|c|c|c|c|}
\hline Model & $\mathrm{R}$ & R Square & Adjusted R Square & $\begin{array}{l}\text { Std. Error of the } \\
\text { Estimate }\end{array}$ \\
\hline 1 & $.865^{\mathrm{a}}$ & .749 & .732 & 1.985 \\
\hline
\end{tabular}

a. Predictors: (Constant), Komitmen Organisasi, Motivasi Kerja, Sistem Informasi, Kualitas Sumber Daya Manusia, Pengendalian Intern

Sumber : Data Diolah, 2021

Tabel 2

Hasil Uji Kelayakan Model ( Uji F) ANOVA $^{b}$

\begin{tabular}{lllllll}
\hline Model & & Sum of Squares & Df & Mean Square & F & Sig. \\
\hline 1 & Regression & 870.250 & 5 & 174.050 & 44.177 & $.000^{\mathrm{a}}$ \\
& Residual & 291.550 & 74 & 3.940 & & \\
& Total & 1161.800 & 79 & & & \\
\hline
\end{tabular}

a. Predictors: (Constant), Komitmen Organisasi, Motivasi Kerja, Sistem Informasi, Kualitas Sumber Daya Manusia, Pengendalian Intern

b. Dependent Variable: Kualitas Laporan Keuangan

Sumber : Data Diolah, 2021 
Journal of Applied Management and Accounting Science. (JAMAS)

(Komang Krishna Yogantara, Gde Herry Sugiarto Asana 85 - 103)

Vol 3, No 1, Desember 2021

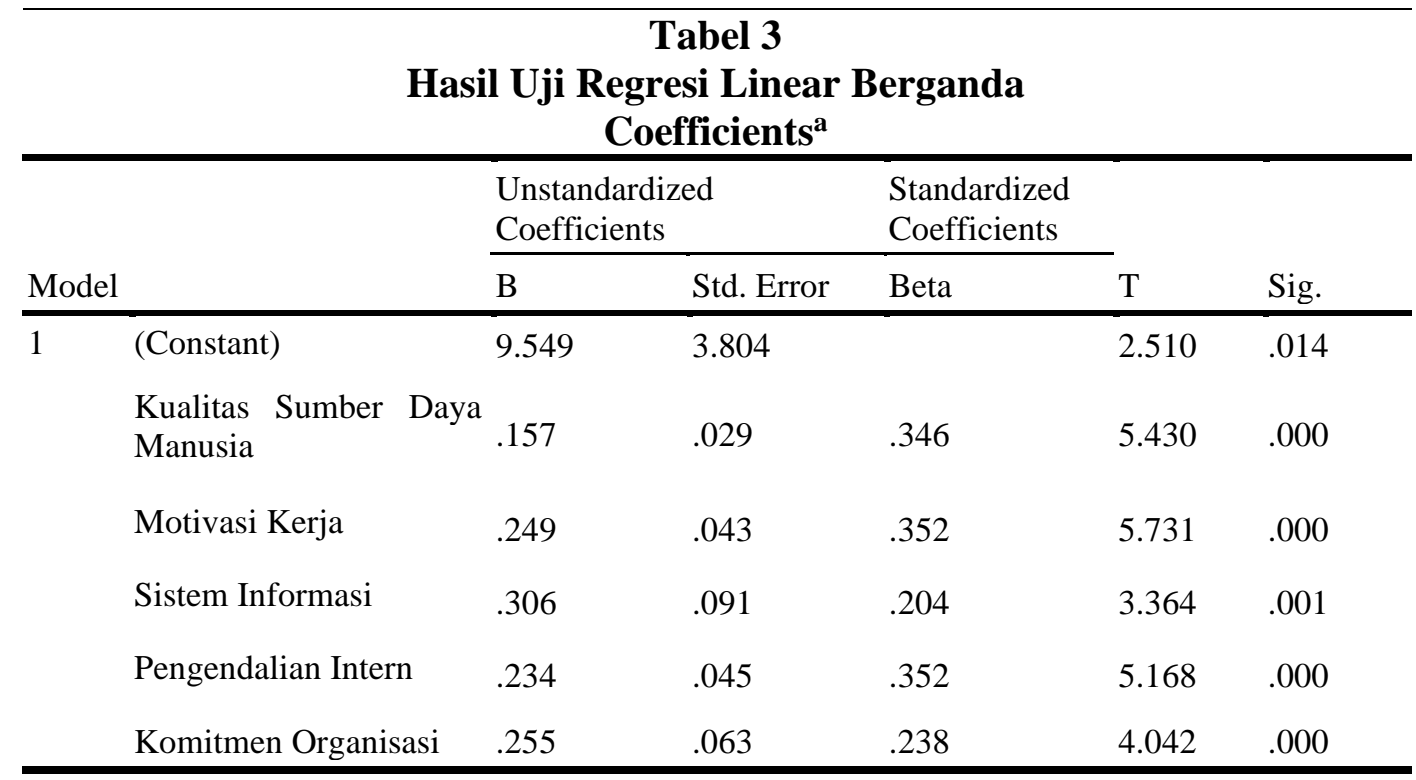

a. Dependent Variable : Kualitas Laporan Keuangan

Sumber : Data Diolah, 2021

Berdasarkan hasil analisis yang disajikan pada Tabel 4.6, maka dapat disusun persamaan regresi sebagai berikut:

$$
\begin{array}{r}
\hat{\mathrm{Y}}=9,549+0,157 \mathrm{X}_{1}+0,249 \mathrm{X}_{2} \\
+0,306 \mathrm{X}_{3}+0,234 \mathrm{X}_{4}+0,255 \mathrm{X}_{5}+\mathrm{e}
\end{array}
$$

Keterangan :

$$
\begin{aligned}
\mathrm{Y}= & \text { Kualitas Laporan Keuangan } \\
& \text { Pemerintah Daerah } \\
\mathrm{a}= & \text { Konstanta } \\
\mathrm{b}= & \text { Koefisien Regresi } \\
\mathrm{X}_{1}= & \text { Kualitas Sumber Daya } \\
& \text { Manusia } \\
\mathrm{X}_{2}= & \text { Motivasi Kerja } \\
\mathrm{X}_{3}= & \text { Pemanfaatan Sistem Informasi } \\
\mathrm{X}_{4}= & \text { Pengendalian Intern } \\
\mathrm{X}_{5}= & \text { Komitmen Organisasi } \\
\mathrm{e}= & \text { Error }
\end{aligned}
$$

\section{Hasil Pengujian Hipotesis}

Secara parsial masingmasing variabel bebas (X) diuji dengan menggunakan uji t untuk mengetahui pengaruh masingmasing variabel tersebut terhadap variabel terikat (Y). Pengujian ini dilakukan agar dapat mengetahui signifikan atau tidaknya pengaruh masing-masing variabel bebas terhadap variabel terikat.
$\mathrm{H}_{1}$ : Pengaruh kualitas sumber daya manusia terhadap kualitas laporan keuangan pemerintah daerah Kabupaten Klungkung

Berdasarkan tabel 4.6 koefisien kualitas sumber daya manusia $\left(B_{1}\right)$ sebesar 0,157 dengan nilai signifikansi 0,000 lebih kecil $\alpha(0,005<0,05)$. Maka $\mathrm{H}_{0}$ ditolak dan $\mathrm{H}_{1}$ diterima. Ini berarti bahwa kualitas sumber daya manusia secara parsial berpengaruh positif dan signifikan pada kualitas laporan keuangan pemerintah daerah. Nilai yang diperoleh menandakan arah hubungan yang positif, dengan demikian dapat dijelaskan bahwa semakin tinggi kualitas sumber daya manusia maka kualitas laporan keuangan pemerintah daerah akan semakin baik, dan begitu pula sebaliknya rendahnya kualitas sumber daya manusia maka akan berdampak pada penurunan kualitas laporan keuangan pemerintah daerah.

$\mathrm{H}_{2}$ : Pengaruh motivasi kerja 
Journal of Applied Management and Accounting Science. (JAMAS)

(Komang Krishna Yogantara, Gde Herry Sugiarto Asana 85 - 103)

Vol 3, No 1, Desember 2021

terhadap kualitas laporan keuangan pemerintah daerah Kabupaten Klungkung

Berdasarkan tabel 4.6

koefisien movitasi kerja $\left(\mathrm{B}_{2}\right)$ sebesar 0,249 dengan nilai signifikansi 0,000 lebih kecil $\alpha$ $(0,005<0,05)$. Maka $\mathrm{H}_{0}$ ditolak dan $\mathrm{H}_{2}$ diterima. Ini berarti bahwa motivasi kerja secara parsial berpengaruh positif dan signifikan pada kualitas laporan keuangan pemerintah daerah. Nilai yang diperoleh menandakan arah hubungan yang positif, dengan demikian dapat dijelaskan bahwa semakin tinggi motivasi kerja maka kualitas laporan keuangan pemerintah daerah akan semakin baik, dan begitu pula sebaliknya rendahnya motivasi kerja maka akan berdampak pada penurunan kualitas laporan keuangan pemerintah daerah.

$\mathrm{H}_{3}$ : Pengaruh pemanfaatan sistem informasi terhadap kualitas laporan keuangan pemerintah daerah

Kabupaten Klungkung

Berdasarkan tabel 4.6 koefisien pemanfaatan sistem informasi $\left(\mathrm{B}_{3}\right)$ sebesar 0,306 dengan nilai signifikansi 0,001 lebih kecil $\alpha(0,005<0,05)$. Maka $\mathrm{H}_{0}$ ditolak dan $\mathrm{H}_{3}$ diterima. Ini berarti bahwa pemanfaatan sistem informasi secara parsial berpengaruh positif dan signifikan pada kualitas laporan keuangan pemerintah daerah. Nilai yang diperoleh menandakan arah hubungan yang positif, dengan demikian dapat dijelaskan bahwa semakin tinggi pemanfaatan sistem informasi maka kualitas laporan keuangan pemerintah daerah akan semakin baik, dan begitu pula sebaliknya rendahnya pemanfaatan sistem informasi maka akan berdampak pada penurunan kualitas laporan keuangan pemerintah daerah.

$\mathrm{H}_{4}$ : Pengaruh pengendalian intern terhadap kualitas laporan keuangan pemerintah daerah Kabupaten Klungkung Berdasarkan tabel 4.6 koefisien pemanfaatan sistem informasi $\left(\mathrm{B}_{4}\right)$ sebesar 0,234 dengan nilai signifikansi 0,000 lebih kecil $\alpha(0,005<0,05)$. Maka $\mathrm{H}_{0}$ ditolak dan $\mathrm{H}_{4}$ diterima. Ini berarti bahwa pengendalian intern secara parsial berpengaruh positif dan signifikan pada kualitas laporan keuangan pemerintah daerah. Nilai yang diperoleh menandakan arah hubungan yang positif, dengan demikian dapat dijelaskan bahwa semakin tinggi pengendalian intern maka kualitas laporan keuangan pemerintah daerah akan semakin baik, dan begitu pula sebaliknya rendahnya pengendalian intern maka akan berdampak pada penurunan kualitas laporan keuangan pemerintah daerah.

$\begin{array}{rrr}\mathrm{H}_{5}: & \begin{array}{l}\text { Pengaruh } \\ \text { organisasi }\end{array} & \text { komitmen } \\ \text { laporan } & \text { kualitas } \\ \text { pemerintah } & \text { daerah } \\ & \text { Kabupaten Klungkung } \\ & \text { Berdasarkan tabel }\end{array}$ koefisien komitmen organisasi $\left(B_{5}\right)$ sebesar 0,255 dengan nilai signifikansi 0,000 lebih kecil $\alpha$ $(0,005<0,05)$. Maka $\mathrm{H}_{0}$ ditolak dan $\mathrm{H}_{5}$ diterima. Ini berarti bahwa komitmen organisasi secara parsial berpengaruh positif dan signifikan pada kualitas laporan keuangan pemerintah daerah. Nilai yang 
diperoleh menandakan arah hubungan yang positif, dengan demikian dapat dijelaskan bahwa semakin tinggi komitmen organisasi maka kualitas laporan keuangan pemerintah daerah akan semakin baik, dan begitu pula sebaliknya rendahnya komitmen organisasi maka akan berdampak pada penurunan kualitas laporan keuangan pemerintah daerah.

\section{Pembahasan Hasil Penelitian}

1. Pengaruh Kualitas Sumber Daya Manusia terhadap Kualitas Laporan Keuangan Pemerintah Daerah di Kabupaten Klungkung Berdasarkan hasil analisis data diperoleh bahwa kualitas sumber daya manusia berpengaruh pada kualitas laporan keuangan pemerintah daerah. Ini ditunjukkan oleh koefisien variabel kualitas sumber daya manusia sebesar 0,157 yang signifikan dengan nilai t-hitung sebesar 5,430 pada $p$ sebesar 0,000. Koefisien kualitas sumber daya manusia yang sudah distandarisasi ditunjukkan dengan beta sebesar 0,346. Hal ini berarti pengaruh langsung kualitas sumber daya manusia pada kualitas laporan keuangan pemerintah daerah adalah $34,6 \%$.

2. Pengaruh Motivasi Kerja terhadap Kualitas Laporan Keuangan Pemerintah Daerah di Kabupaten Klungkung

Berdasarkan hasil analisis data diperoleh bahwa motivasi kerja berpengaruh pada kualitas laporan keuangan pemerintah daerah. Ini ditunjukkan oleh koefisien variabel motivasi kerja sebesar 0,249 yang signifikan dengan nilai t-hitung sebesar 5,731 pada $\mathrm{p}$ sebesar 0,000. Koefisien motivasi kerja yang sudah distandarisasi ditunjukkan dengan beta sebesar 0,352 . Hal ini berarti pengaruh langsung motivasi kerja pada kualitas laporan keuangan pemerintah daerah adalah $35,2 \%$.

3. Pengaruh Pemanfaatan Sistem Informasi terhadap Kualitas Laporan Keuangan Pemerintah Daerah

Berdasarkan hasil analisis data diperoleh bahwa pemanfaatan sistem informasi berpengaruh pada kualitas laporan keuangan pemerintah daerah. Ini ditunjukkan oleh koefisien variabel pemanfaatan sistem informasi sebesar 0,306 yang signifikan dengan nilai t-hitung sebesar 3,364 pada $\mathrm{p}$ sebesar 0,001. Koefisien pemanfaatan sistem informasi yang sudah distandarisasi ditunjukkan dengan beta sebesar 0,204 . Hal ini berarti pengaruh langsung pemanfaatan sistem informasi pada kualitas laporan keuangan pemerintah daerah adalah $20,4 \%$.

4. Pengaruh Pengendalian Intern terhadap Kualitas Laporan Keuangan Pemerintah Daerah di Kabupaten Klungkung

Berdasarkan hasil analisis data diperoleh bahwa pengendalian intern berpengaruh pada kualitas laporan keuangan pemerintah daerah. Ini ditunjukkan oleh koefisien variabel pengendalian intern sebesar 0,234 yang signifikan dengan nilai t-hitung sebesar 5,168 pada $\mathrm{p}$ sebesar 0,000 . Koefisien pengendalian intern yang sudah distandarisasi ditunjukkan dengan beta sebesar 0,352 . Hal ini berarti pengaruh langsung pengendalian intern pada kualitas laporan keuangan pemerintah daerah adalah $35,2 \%$. 
5. Pengaruh Komitmen Organisasi terhadap Kualitas Laporan Keuangan Pemerintah Daerah di Kabupaten Klungkung

Berdasarkan hasil analisis data diperoleh bahwa komitmen organisasi berpengaruh positif pada kualitas laporan keuangan pemerintah daerah. Ini ditunjukkan oleh koefisien variabel komitmen organisasi sebesar 0,255 yang signifikan dengan nilai t-hitung sebesar 4,042 pada $\mathrm{p}$ sebesar 0,000. Koefisien komitmen organisasi yang sudah distandarisasi ditunjukkan dengan beta sebesar 0,238 . Hal ini berarti pengaruh langsung komitmen organisasi pada kualitas laporan keuangan pemerintah daerah adalah $23,8 \%$.

\section{SIMPULAN DAN SARAN Simpulan}

Berdasarkan pembahasan hasil penelitian dari bab sebelumnya terhadap variabel-variabel bebas yang mempengaruhi kualitas laporan keuangan pemerintah daerah yang diukur dengan variabel kualitas sumber daya manusia, motivasi kerja, pemanfaatan sistem informasi, pengendalian intern, dan komitmen organisasi dapat disimpulkan sebagai berikut :

1) Kualitas sumber daya manusia berpengaruh positif dan signifikan pada kualitas laporan keuangan pemerintah daerah. Hasil penelitian ini menunjukkan bahwa semakin baik kualitas sumber daya manusia yang dimiliki oleh pegawai di SKPD Kabupaten Klungkung dalam melaksanakan suatu tugas untuk membuat laporan keuangan maka kemampuan dalam membuat laporan keuangan akan semakin baik.

2) Motivasi kerja berpengaruh positif dan signifikan pada kualitas laporann keuangan pemerintah daerah. Hasil penelitian ini menunjukkan bahwa semakin tinggi motivasi kerja yang diberikan kepada pegawai di SKPD Kabupaten Klungkung maka kualitas laporan keuangan yang dibuat juga akan memberikan hasil yang baik.

3) Pemanfaatan sistem informasi mempunyai pengaruh positif dan signifikan pada kualitas laporan keuangan pemerintah daerah. Hasil penelitian ini menunjukkan bahwa semakin tinggi pemanfaatan sistem informasi maka kualitas laporan keuangan Pemerintah Daerah akan semakin baik.

4) Sistem pengendalian intern mempunyai pengaruh positif dan signifikan pada kualitas laporan keuangan Pemerintah Daerah. Hasil penelitian ini menunjukkan bahwa semakin tinggi sistem pengendalian intern, maka kualitas laporan keuangan pemerintah daerah semakin baik.

5) Komitmen organisasi mempunyai pengaruh positif dan signifikan pada kualitas laporan keuangan pemerintah daerah. Hal ini berarti semakin tinggi komitmen organisasi. Hal ini berarti semakin tinggi komitmen organisasi yang dimiliki oleh pegawai di SKPD Kabupaten Klungkung, maka kualitas laporan keuangan pemerintah daerah semakin baik.

\section{Saran}

Berdasarkan simpulan yang
telag diuraikan, maka dapat
disampaikan beberapa saran sebagai
berikut:


1) Khusus untuk sumber daya manusia yang bekerja di dalam bagian keuangan agar membiasakan diri untuk membaca literatur berupa jurnal akuntansi dan buku-buku akuntansi dalam rangka mengupgrade dan mengerti pengetahuannya di bidang akuntansi. Sehingga dapat menciptakan laporan keuangan yang sesuai dengan aturan-aturan akuntansi yang ada. Pada pemanfaatan sistem informasi, petugas di bidang Sistem Akuntansi Intansi (SAI) agar menjaga kerahasiaan dan keamanan data. Dalam sistem pengendalian setidaknya pimpinan telah melakukan analisis risiko secara lengkap dan menyeluruh terhadap kemungkinan timbulnya pelanggaran pada sistem akuntansi. Untuk komitmen organisasi di dalam sebuah instansi setidaknya konsisten terhadap pekerjaannya yang sesuai dengan bidangnya agar pekerjaan yang dilakukan membuahkan hasil yang baik. Dengan demikian dapat memberikan nama baik untuk organisasinya, dan yang terakhir untuk kualitas laporan keuangan. Selanjutnya agar selalu mentaati kebijakan-kebijakan akuntansi yang sering berubah agar sesuai dengan peraturan SAI yang ada dan terciptanya laporan keuangan yang berkualitas.

2) Bagi peneliti selanjutnya diharapkan dapat mengembangkan penelitian ini dengan menambahkan variabel lainnya yang memiliki pengaruh terhadap kualitas laporan keuangan pemerintah daerah dengan mengambil sampel di SKPD lainnya.

\section{DAFTAR PUSTAKA}

Adhi, Yohanes Suharjo. 2013. Pengaruh Penerapan Standar Akuntansi Pemerintahan dan Kualitas Sumber daya manusia Pemerintah Daerah Terhadap Kualitas Laporan Keuangan (Studi kasus pada pemerintah kota tual). Jurnal Akuntansi, Vol. 5 No. 3, Hal, 1-19

Afiah, N.N. Rahmatika, D.N.2014. Factors Influencing The Quality Of Financial Reporting And Its Implications On Good Government Governance (Research On Local Government Indonesi). International Journal of Business, Economics and Law, 5 (1): 111-121

Agoes, Sukrisno.2012. Auditing Petunjuk Praktis Pemeriksaan Akuntan Oleh Akuntan Publik Jilid 1 Edisi Keempat.Salemba Empat. Jakarta.

Arlia Sari Artana.2016). Pengaruh Pemahaman Standar Akuntansi Pemerintah, Pemanfaatan Sistem Informasi Akuntansi Keuangan Daerah dan Sistem Pengendalian Internal Terhadap Kualitas Laporan Keuangan Pemerintah Daerah. Skripsi. Fakultas Ekonomi dan Bisnis Universitas Islam Negeri Syarif Hidayatullah Jakarta.Hal : 1315

Aryani, farida. 2013. Analisis Faktor - Faktor Yang Mempengaruhi Kualitas Laporan Keuangan Kementerian Negara/Lembaga Satuan Kerja Mitra Kppn Medan Ii. Tesis Megieter. 
Journal of Applied Management and Accounting Science. (JAMAS)

(Komang Krishna Yogantara, Gde Herry Sugiarto Asana 85 - 103)

Vol 3, No 1, Desember 2021

Universitas Sumatera Utara. Medan

Choirunisah, F.2008. Faktor-faktor yang Mempengaruhi Kualitas Informasi Laporan Keuangan yang dihasilkan Sistem Akuntansi Instansi. (Tesis).Yogyakarta: UGM

Darmayani.2014. Pengaruh Kualitas Sumber Daya Manusia, Penerapan Sistem Informasi Pengelolaan Keuangan Daerah (SIPKD), dan Pengendalian Intern Terhadap Nilai Laporan Keuangan pada Bagian Keuangan SETDA Kabupaten Buleleng. e-Journal S1 Ak Universitas Pendidikan Ganesha Jurusan Akuntansi Program S1 Volume 2 No: 1 Tahun 2014

Desi Indriasari, Ertambang Nahartyo. 2009. Pengaruh kapasitas SDM, Pemanfaatan Teknologi Informasi dan Pengendalian Intern Akuntansi terhadap Keterandalan dan Ketepatwaktuan Pelaporan Keuangan Pemerintah Daerah, Studi pada Pemerintah kota Palembang dan Kabupaten Ogan Ilir. Jurnal Akuntansi.

Dewi, N.P. Erawati, N.M.A.2014. Pengaruh Partisipasi Penganggaran, Informasi Asimetris, Penekanan Anggaran dan Komitmen Organisasi Pada Senjangan Anggaran. E-Jurnal Akuntansi Universitas Udayana.

Faristiana. 2011. Faktor-faktor yang Mempengaruhi Keandalandan
Timeliness Pelaporan Keuangan Badan Layanan Umum.Skripsi. Akuntansi Fakultas Ekonomi Universitas Diponegoro Semarang. Hal 30-31.

Firdaus. 2015. Pengaruh Kualitas Sumber Daya Manusia Pemanfaatan Teknologi Informasi dan Penerapan Kebijakan Akuntansi Terhadap Kualitas Laporan Keuangan Pemerintah Kota Banda Aceh. Tesis. Fakultas ekonomi Universitas Syiah Kuala Banda Aceh.

Julita, Santi. 2010. Relationship Between Organisasional Commitment, Locus of Control and Radiness to Change Among Nurses. Thesis. Malaysia. International Islamic University.

Iman Zare.2012. Study of effect of accounting information systems and softwares on qualitative features of accounting information. International Journal of Management Sciences and Business Research, 1(4).

Indriasari, D.Ertambang N. 2008. Pengaruh Kapasitas Sumber Daya Manusia, Pemanfaatan Teknologi Informasi, dan Pengendalian Intern Akuntansi terhadap Nilai Informasi Pelaporan Keuangan Pemerintah Daerah (Studi pada Pemerintah Kota Palembang dan Kabupaten Ogan Ilir). Simposium Nasional Akuntansi XI, Pontianak, 23-24 Juli.

Irwan, D.2011.Pengaruh Penerapan Sistem Pengendalian Intern 
Journal of Applied Management and Accounting Science. (JAMAS)

(Komang Krishna Yogantara, Gde Herry Sugiarto Asana 85 - 103)

Vol 3, No 1, Desember 2021

Pemerintah, Kompetensi

Sumber Daya Manusia dan

Penerapan Standar Akuntansi

Pemerintahan terhadap Kualitas

Laporan Keuangan Pemerintah

Provinsi Sumatera Barat".

(tesis). Universitas Negeri

Padang.

Kadarisman M. 2012.Manajemen

Pengembangan Sumber Daya

Manusia. Jakarta: PT Raja

Grafindo Persada

Karmila, Amries Rusli Tanjung dan

Edfan Darlis.2014. Pengaruh

Kapasitas Sumber Daya

Manusia, Pemanfaatan

Teknologi Informasi dan

Pengendalian Intern Terhadap

Keterandalan Pelaporan

Keuangan Pemerintah Daerah

(Studi pada Pemerintah Provinsi

Riau). Jurnal Sorot Universitas

Riau, Vol. 9, No. 1,Hal. 25-42.

Kartopawiro, Sardio dan Yohanes

Susanto. 2018. Analisis

Terhadap Kinerja Laporan

Keuangan Pemerintah Daerah

Kabupaten Musi Rawas. Jurnal

Manajemen dan Bisnis

Sriwijaya Vol.16 (1), 2018

Lodhrakentjana, Baja dan Elvira Luthan. 2019. Motivasi, Kepuasan Kerja, Komitmen Pegawai Akuntansi dan Kualitas Laporan Keuangan Pemerintah Daerah pada Pemerintah Kota Depok. Jurnal Riset Akuntansi dan Perpajakan, JRAP Vol. 1 no. 2, hal 187-199

Mahaputra, I.P.U.R. Putra, I.W. 2014. Analisis Faktor - Faktor yang mempengaruhi Kualitas

Informasi Pelaporan Keuangan

Pemerintah Daerah. Jurnal

Akuntansi Universitas

Udayana,8 (2): 230-244

Mohmmaed and Eleswed.2013.Job

Satisfaction and Organizational

Commitment: A Correlational

Study in Bahrain.International

Journal of Business,

Humanities and Technology

Noprial. 2015. Pengaruh Kualitas

Sumber Daya Manusia,

Komitmen Organisasi, Sistem

Pengendalian Intern, dan

Pemanfaatan Teknologi

Informasi Terhadap Kualitas

Laporan Keuangan. Jurnal

Faculty of Economics Riau

University, Pekanbaru,

Indonesia Vol. 2 No. 2.

Nurillah, A.S. Muid D. 2014. Pengaruh Kompetensi Sumber Daya Manusia, Penerapan Sistem Akuntansi Keuangan Daerah (SAKD), Pemanfaatan Teknologi Informasi, dan Sistem Pengendalian Intern terhadap Kualitas Laporan Keuangan Pemerintah Daerah (Studi Empiris pada SKPD Kota Depok). Jurnal Akuntansi Fakultas Ekonomika dan Bisnis Universitas Diponegoro, 3 (2)Tahun 2014.

Ogah, Idagu Joseph. 2013. An Evaluation of Accounting Systems as a Management Decision Tool in Union Bank of Nigeria Plc, Uyo Branch of Akwa Ibom. Greener Journal of Business and Management Business Study, 3 (1), pp: 38-45 
Journal of Applied Management and Accounting Science. (JAMAS)

(Komang Krishna Yogantara, Gde Herry Sugiarto Asana 85 - 103)

Vol 3, No 1, Desember 2021

\section{Peraturan Pemerintah Republik Indonesia Nomor 71 Tahun 2010 Tentang Standar Akuntansi Pemerintahan, artikel diakses pada tanggal 1 April 2017, diakses dari http://www.djpk.depkeu.go.id/a ttach/post-pp-no-71-tahun- 2010-tentang-standar akuntansi- pemerintahan/PP71.pdf}

Porter, L.W., R. Steers, R. Mowdey and P. Boulian. 1974. Organization Commitment, Job Statisfaction and Turnover among Phychiatric Techniciants. Journal Applied Psycology. Vol. 59, October.

Pujiswara, Ida Bagus, Nyoman Trisna Herawati dan Ni Kadek Sinarwati. 2014. Pengaruh Pemanfaatan Sistem Informasi Akuntansi Keuangan Daerah dan 100 Pengawasan Keuangan Daerah terhadap Nilai Informasi Pelaporan Keuangan dan Akuntabilitas Pemerintah Daerah (Studi pada Satuan Kerja Perangkat Daerah di Kabupaten Klungkung). $e$ Journal S1 Ak Universitas Pendidikan Ganesha, Vol 2 No. 1

Punjanira, Putriasri Dan Abdullah Taman. 2017. Pengaruh Kompetensi Sumber Daya Manusia, Penerapan Standar Akuntansi Pemerintahan, Dan Penerapan Sistem Akuntansi Keuangan Daerah Terhadap Kualitas Laporan Keuangan Pemerintah Daerah Provinsi Diy. Jurnal Nominal / Volume Vi Nomor 2 / Tahun 2017
Sari, Maeka, M.YN. PI Made Pradana Adiputra, Edy Sujana.2014. Pengaruh Pemahaman Standar Akuntansi Pemerintahan (Sap) dan Pemanfaatan Sistem Informasi Akuntansi Keuangan Daerah terhadap Kualitas Laporan Keuangan Pemerintah Daerah (Studi Kasus Pada Dinas-Dinas di Pemerintah Kabupaten Jembrana). eJournal S1 Ak Universitas Pendidikan Ganesha, Vol 2 No. 1, 2014.

Sari, N. K. I., \& Yogantara, K. K. 2020. PENGARUH

KEPUASAN KERJA, KOMITMEN ORGANISASI DAN PARTISIPASI ANGGARAN TERHADAP KINERJA MANAJERIAL ACCOUNTING DEPARTEMENT HOTEL BINTANG 5 DI KABUPATEN BADUNG. Journal Research of Accounting (JARAC), 2(1), 106115.

Setiyawati, H. 2013. The effect of Internal Accountants' Competence, Managers' Commitment to Organizations and the Implementation of the Internal Control System on the Quality of Financial Reporting. International Journal of Business and Management Invention, 2 (11): 19-27.

Sumarti, Titik. 2007. Pengaruh Motivasi Terhadap Komitmen Organisasional Melalui Kepuasan kerja (Studi pada Perawat Instalasi Rawat Inap I RSU Dr. Saiful Anwar Malang). Fakultas Ekonomi 


\section{Universitas Negeri Malang. Malang.}

Udiyanti, Ari, Nyoman, N. L, Atmadja, T.A \& Darmawan, Surya, A.N.2014. Pengaruh Penerapan Standar Akuntansi Pemerintahan, Sistem Pengendalian Internal, dan Kompetensi Staf Akuntansi terhadap Kualitas Laporan Keuangan Pemerintah Daerah (Studi Kasus Pada SKPDKabupaten Buleleng).eJournal S1 Ak Universitas Pendidikan Ganesha, Vol 2 No 1 ,

Winanrdi. 2007. Motivasi Pemotivasian Dalam Managemen. Jakarta : PT Raja Grafindo Persada

Yensi, S.D, Amir Hasan dan Yun Manusia, Penerapan Sistem Akuntansi eita Anisma. 2014. Pengaruh Kompetensi Sumber Daya Keuangan Daerah, dan Sistem Pengendalian Intern (Internal Audit) terhadap Kualitas Laporan Keuangan Pemerintah Daerah (Studi Empiris pada SKPD Kabupaten Kuantan Singingi)", Jom Fekon, Vol. 1. Hal 1-15, 2014.

Yogantara, K. K. 2021. MINAT INVESTASI MAHASISWA DI PASAR MODAL DAN FAKTOR-FAKTOR YANG MEMPENGARUHINYA. Jour nal of Applied Management and Accounting Science, 2(2), 143152.

Yudianta, I. G .A. Erawati, N.M.A.2012. Pengaruh Sumber
Daya Manusia, Teknologi Informasi dan Pengendalian Intern terhadap Kualitas Laporan Keuangan.Jurnal Akuntansi Universitas Udayana, Vol. 1, No. 1, November 2012. 